\title{
Extreme heterogeneity of Sr-Nd-Pb in melt inclusions from Latera (Italy) resulting from complex subduction dynamics
}

JANNE M. KOORNNEEF ${ }^{1}$ AND IGOR K. NIKOGOSIAN ${ }^{2}$

${ }^{1}$ Vrije Universiteit

${ }^{2}$ VU Amsterdam

Presenting Author: j.m.koornneef@vu.nl

Geodynamic processes at destructive plate boundaries contribute to the observed geochemical heterogeneity in worldwide lavas. Melt inclusions (MI) hosted by primitive highforsterite olivine typically record greater geochemical variability than host lavas and better reflect the heterogeneity of magma sources.

Post-collisional magmatism in Italy produces potassium-rich volcanism that indicates an important role of recycled sediments that varied in composition in both space and time. Latera volcano, in the northern Roman Magmatic Province erupted high-potassium (HKS) and shoshonitic (SHO) rock series. MI in olivine from the shoshonitic Selva del Lamone lava indicate that melts are derived from two contrasting mantle domains carrying recycled subducted components from the Alpine and the Adriatic subduction phases; both upper and ancient lower continental crust [1].

Here we report coupled $\mathrm{Sr}-\mathrm{Nd}-\mathrm{Pb}$ isotope data on olivinehosted fluid-rich melt inclusions with exotic characteristics; depleted $\mathrm{CaO}$ and $\mathrm{Sr}$, but enriched in $\mathrm{MgO}, \mathrm{Pb}, \mathrm{Zr}$, Hf compared to the host lavas. Raman spectroscopy of the fluids that occur isolated or as exsolved phases within MIs indicates the presence of nitrogen.

The MI isotopic compositions confirm that source components not resolved by analysis of bulk lava can be discriminated. The ${ }^{87} \mathrm{Sr} /{ }^{86} \mathrm{Sr}$ range from $0.70957 \pm 5$ to $0.71002 \pm 2$ and have significantly less radiogenic compositions (568 ppm) compared to the host lava, but ${ }^{143} \mathrm{Nd} /{ }^{144} \mathrm{Nd}$ ratios are invariable and indistinguishable from the host lavas. In contrast, $\mathrm{Pb}$ isotope ratios are highly variable with much more unradiogenic $\mathrm{Pb}$ isotopic compositions with a minimum to maximum difference between the host lava and MIs of 1 to $4 \%$ for ${ }^{206} \mathrm{~Pb} /{ }^{204} \mathrm{~Pb}, 2$ to 5 \%o for ${ }^{207} \mathrm{~Pb} /{ }^{204} \mathrm{~Pb}$ and $7 \%$ o to $3 \%$ for ${ }^{208} \mathrm{~Pb} /{ }^{204} \mathrm{~Pb}$.

The combined geochemical signatures suggest the presence of an old crustal component that lost its $U$ to freeze in the unradiogenic $\mathrm{Pb}$, but that is very different in major and trace element compositions from the component that was found below Roccamonfina-Ernici [2]. It is inferred that the older Alpine subduction of the Ligurian Piemonte basin introduced nitrogenrich fluids and sediments with unradiogenic $\mathrm{Pb}$ composition.

[1] Nikogosian et al., 2016, EPSL. 449, 12-19 [2] Koornneef et al., 2019, Nature Communications. 10, 3237 